Anton Grad: Word-order in Old and Middle English

Anton Grad

\title{
A CONTRIBUTION \\ TO THE PROBLEM OF WORD-ORDER IN OLD AND MIDDLE ENGLISH
}

An interesting, though not very common phenomenon in Current English word-order is afforded by the occurrence of the inverted subject (inverted word-order, VS) in declarative sentences ${ }^{1}$ which is, on the one hand, far less frequent than in German and Scandinavian languages ${ }^{2}-$ in this respect English goes parallel with French -, and, on the other hand, also far less frequent than in Old and Middle English, both resorting to the inverted word-order in many cases in which it is no longer admitted in Current English. ${ }^{3}$ Thus we meet - among other cases of its use in older English - the inversion of the subject especially in the so-called introduced declarative sentences, e. g.:

a) after the stressed (emphatic) object in the front position of the sentence: pas lareoroas asende se eadiga papa Gregorius, Aelfric; raelraeste geceas Byrhtnodes maeg, The Battle of Maldon; me sendon to pe saemen snelle, ib.; Hem oftok a menestral, Iacob and Iosep; Hym louede yung, him louede holde, Erl and barun, The Lay of Havelok the Dane 30; $V$ tlames and theues made he bynde, ib.; A fat stoan loved he best of any roost, Chauc., Cant.Tales, Prologue 206; but hood, for jolitee, mered he noon, ib. 680 , etc.

In Current English the frontal object does not occasion the inversion of the subject (expressed either by a noun or a personal pronoun), comp.: Numbers of the men she knem already, Thack., Van. Fair, ch. 29; The great sea-chest none of us had ever seen open, Stevenson, Treas. Island,

${ }^{1}$ Comp. Jespersen, A Modern English Grammar on Historical Principles (MEG) VII $2.22 \mathrm{ff}$; Poutsma, A Grammar of Late Modern English, Part I, Ch. VIII $5 \mathrm{ff}$.

2 Jespersen, Gromth and Structure of the English Language, 3rd ed., \$ 14, Id., MEG VII 2.18; Aronstein, Englische Stilistik, \$ 24; Poutsma, o. c., P. I, VIII 6; for German comp. Behaghel, Deutsche Syntax IV, § 1466, Heyse, Deutsche Grammatik, 29. Aufl., pp. 546 f.

${ }^{3}$ Jespersen, MEG VII 2.19, 2.49; Einenkel, Geschichte der englischen Sprache II, Historische Syntax, $\$ 59 \eta$; Aronstein, 1. c.; the same development is also stated for Old and Middle French, cp. Foulet, Petite syntaxe de l'ancien francais, 3e éd., \$ 450; Lerch, Historische französische Syntax III, \$ 395 ff; Dauzat, Histoire de la langue francaise, $\$ 514$, ascribes the Old French inversion to the Germanic influence. 
ch. 1; The second minter at Malta Joan enjoyed less, Baring, Darby and Joan, ch. 13; A man so overfloroing with health and life he had seldom seen, Galsw., Maid in Waiting, ch.4, etc.

The inversion, however, is the rule also in Current English after a negative frontal object: Not another mord had he to say to me, Stev., Kidnapped, ch. 4; But no knob or spring could me discover, Haggard, King Solomon's Mines, ch. 17; They got into their cab, and not one word did they say the rohole ray home, Galsw., Maid in Wait., ch. 35; We abate nothing of our just demands; not one jot or title do me recede, W. Churchill, The Second World War II, ch. 10, etc. ${ }^{4}$

b) after the frontal adverbial adjunct: pa aras sum aegleam man, Gospel, Luke X 25; Ond paes on Eastron rorhte Aelfred cyning lytle merede gemeorc, Winchester $\mathrm{Chr}$.; On pam dagum rixode Aepelbyrht cyning on Cantmarebyrig riclice, Aelfric, Lives of the Saints; On al pis yuele time heold Martin abbot his abbotrice $X X$ rintre and half gaere, Peterborough Chr.; pis gaere for pe king Stephne ofer sae to Normandi, ib.; This thretty mynter... hath he gone and preched, Piers Plowman, etc.

In Current English the inversion of the subject is regularly brought about by negative frontal adverbs and adverbial adjuncts, as well as after some adverbs which are not negative in form, but are felt as negative, thrown by emphasis to the front position; inversion is, however, very frequent with intransitive verbs and in passive constructions when the subject, being a more weighty word than the predicate, is placed towards the end of the sentence; thus in: Never mould she shom him or that girl that they could hurt her, Galsw., Beyond II 3; in none of his plays had he ever come so near the truth, Deeping, The Bridge of Desire, ch. 36; No sooner does one expect you to go straight on ... than you double round the corner, Hardy, Jude the Obscure VI 4; Not for a hundred years have the relations between Moslems and Hindus been so poisoned, Churchill, o. c. I 5; for hardly had Ahab reached his perch; hardly mas the rope belayed to its pin ... rhen .... Melville, Moby Dick, ch. 134; Only in Richmond Park did she remember that ..., Galsw., Indian Summer of a Forsyte, ch. 2; Only mhen they left the house... did his normal eloquence return, Cronin, Citadel I 4; Rarely has so generous a proposal encountered such a hostile reception, Churchill, o. c. II 10; Finally came the parting with Miss Amelia..., Thack., Van. Fair, ch. 6;

- Poutsma, o. c., P. I, VIII 11; Grad, Affectivity and Inversion in Modern English, in Zbornik filozofske fakultete II, Ljubljana 1955. 
With Hubert's fate roas rrapped up the fate of her beloved home, Galsw., Maid in Wait., ch. 1; In Dinny flamed up compassion for young Croom, Id., Over the River, ch. 31, etc. ${ }^{5}$

c) after a predicative thrown by emphasis to the front position: Ful morthy mas he in his lordes merre, Chauc., Cant. Tales, Prol. 47; Whyt roas his berd, ib. 331; Fair mas this yonge ryf, ib., The Milleres Tale 3233, etc.; comp. still Sh., R. Jul. III 1: Villain am I none.

In Current English the inversion is still observed with a substantival subject: Great mas Mr. Tulliner's monder, Eliot, The Mill on the Floss I 11; An amazing fellom mas Henry, A. Bennet, Riceyman Steps II 4, etc. But: Beautiful rhite it mas, Galsw., Over the River, ch. 2; A poor lot they are, Id., The Island Pharisees, ch. 7, etc. ${ }^{6}$

As may be seen from the above instances of the old period, the second place in the sentence was occupied by the verb, attracted there by its modifier, i. e. the stressed frontal object, and adverbial adjunct respectively; in this way the subject, whose place in non-introduced declarative sentences was normally in front of the verb as early as that period, was thrown after it.

It must be admitted, however, that in the examples of the above kind the direct (non-inverted, regular) word-order, too, is often to be found in older English, a fact explicitly pointed out also by Mossé, Manuel de l'anglais du moyen âge II, $\$ 173,3$, who in a note states the non-compulsory use of the inversion in such cases, giving at the same time the following two instances: sume hi diden in crucethus, Peterborough Chr. 29; al pou most sugge, The Fox and the Wolf 207.

Mossé puts too little stress on the fact that the direct arrangement is met with especially in cases in which the subject is expressed by a personal pronoun. Comp. also: nu ic neom noyrde paet ic beo pin suna nemned, Gospel, Luke XV 19; Nu bu me forlaered haefst on mines herran hete, Genesis; Rihtlice hi sind Angle gehatene, Aelf ric, Lives of the Saints; Aefter pysum rordum, he geroende to pam aerend-racan, ib.; sume treorou he matrode to pam paet hie py smiðor sceoldon meaxan, Cura Past.; paet roif he onfeng fram hiere ieldrum, Bede's Eccl. Hist.; A pousent shep ich habbe abiten, The Fox and the Wolf 203; Mani busen hi drapen mid hungaer, Peterb. Chr.; Calibeorne his smeord he smeinde bi his side, Lazamon's Brut 21133; His spere he nom an honde,

s. Jespersen, MEG VII 2.41; Poutsma, o. c., P. I, VIII 7 a; Grad, o. c.

6 Jespersen, MEG VII 2.31; Poutsma, o. c., P. I, VHI 18; Grad, o. c. 
ib. 21144; Ricth-mise men he louede alle, The Lay of Havelok the Dane 37; Ful ofte tyme he hadde the bord bigonne, Chauc., Cant.Tal., Prol. 52 (frequent construction in Chaucer!); To herte knyf hue (=she) sette, King Horn 101; $\mathrm{Nu}$ ze habbep iherd pane ende of Floriz, Floriz and Blancheflur 181, etc.

As early as that period, and probably under the influence of the numerous cases with the non-inverted personal pronoun, the direct wordorder is also to be found in far less numerous examples with a substantival subject, as in: In pat time al Hengelond perl Godrich hauede in his hond, Havelok the Dane 999; po pe bataile mas ido, The Chronicle of Rob. of Gloucester 108; The reule of seint Maure... This ilke monk leet olde thinges pace, Chauc., C.T., Prol. 173; Therfore, in stede of meping and preyeres, Men moot yeve silver to the povre freres, ib. 251, etc.

As appears from the statistics given by Huchon, Histoire de la langue anglaise I 257 , the inverted word-order in such cases was still predominant in Old English (Chronicle 3:2, Cura Past. $3: 2$, Aelfric's Homilies $3: 1$ ), but the percentage of instances of the direct arrangement were already considerable in that period and were constantly increasing in the course of the following centuries, especially sharply when, with the collapse of declension, the direct arrangement was given a syntactic function, becoming, as a sort of "morphème", ${ }^{7}$ vital to the understanding of sentences of the subject-verb-object pattern $;^{8}$ the numerous examples of non-inversion, especially resorted to in cases with a pronominal subject, show that older English, as it were, overtook contemporary French where in similar cases even the pronominal subject had strictly to obey the Old French rule of inversion, comp.: Karlun avrum nus ja, Rol.; Vers Engletere passat il la mer salse, ib. 372; or sai jo veirement que..., ib.; ja n'en descendrat il, Voyage de Charlemagne; Aultre chose ne şay-je, Cent nouvelles nouvelles, No. 36; comp. as late as the $17^{\text {th }}$ century: Une chose ai-je à dire, La Fontaine, Contes III 6, etc.

7 J. Vendryes, Le Langage, p. 95.

8 Comp. Jespersen's statistics for this pattern in older English: $40 \%$ in Alfred's prose, only $16 \%$ in Beowulf (poetry!), but $66 \%$ in Ancren Riwle (13th cent.), $84 \%$ in Chaucer's prose (Jespersen, MEG VII 2.18).

H. Reis states that one quarter of all principal clauses in Beowulf exhibits the object (adverbial adjunct) - subject - verb pattern, and sees in this wordorder a survival of one of the three possible Old Germanic arrangements (H. Wunderlich-H. Reis, Der deutsche Satzbau, 3. Aufl, p. 94 ff).

- The pronoun-subject could be still omitted in the old period of French, cp. Foulet, o. c., \$ 457, Lerch, o. c., \$ 395, Note. 
The strong tendency to use the pronominal subject in front of the verb in the English of that period is clearly proved by examples in translations and adaptations from French in which we already meet the direct word-order in the English construction in spite of the French inversion, comp.: Nou pou hest y-hyerd pe zennes, The Ayenbite of Inwyt (French original: Ore as-tu oi les pecchiéz); And pervore pet zuyche zennes arizep communliche ine taberne, pet is welle of zenne, pervore ich roylle a lite take of pe zennes, ib. (French: ...por ce voel je un poi toucher des pecchiéz); baz pou ssoldest to cleve, ich nelle nazt lete asskapie pis mes, ib. (French: Se tu deooies crever, ne lairai-je pas ce mes eschaper), etc. Owing to such examples one cannot quite agree with the view of J. Delcourt ${ }^{10}$ that "l'anglais a dû suivre en cela (sc. ordre des mots) l'exemple que lui avait montré le français qui de bonne heure avait substitué l'ordre direct à l'inversion germanique", but, on the contrary, it may be assumed that already at this early date the tendency in English to conform to the direct arrangement in the so-called introduced sentences began to take root more intensively and probably prior to the similar development in French. It should also be observed that this tendency - probably first realised in the cases with a pronominal subject (euphonic and rhythmic considerations also playing an important part in this development ${ }^{11}$ ) - originated at a time when phonetic development had not yet reduced or eliminated the old declensional endings, a fact which argues in favour of the hypothesis expressed by Jespersen ${ }^{12}$ who supposes that the direct (logical) arrangement began to predominate already before the decay of the old declension, or, in other words, the origin of the new fixed direct word-order is not due, as is usually assumed, to the decay of the inflectional system in Old and Middle English. ${ }^{13}$

$10 \mathrm{~J}$. Delcourt, Initiation à l'étude historique de l'anglais, 1944, $\$ 272$.

${ }^{11}$ Hirt, Handbuch des Urgermanischen III 217, giving the example: niper he ahreas, even thinks this arrangement a survival of the older word-order when the unstressed ("tiefbetont") personal pronoun used to precede the (also weakly stressed) verb and occupy the second place in the sentence, i. e. immediately after the stressed front-word ("Wackernagels Gesetz").

12 Jespersen, Language, its Nature, Development and Origin XVIII, \$ 13; comp. also Id., Progress in Language, \$ 75.

${ }^{13}$ For French as well, Lerch, o. c. III $269 \mathrm{ff}$, denies any connection between the decay of the two-case Old French declension and the establishment of a fixed, uniform arrangement. 
In connection with the problem of inversion, we shall deal in these pages with the question whether in the old stage of the language the inversion of the subject also took place in the principal clause when this was preceded by a subordinate clause (usually an adverbial clause); inversion is, as known, rigorously observed in Modern German ${ }^{14}$ and Scandinavian languages, but it does not take place in Modern English - at least not with transitive verbs, nor with intransitive verbs with a pronominal subject ${ }^{15}$, which in this respect again agrees with Modern French. Comp.:

Mod. E.: When I entered his room, he (my father) ras reading a letter. Fr.: Quand j'entrai (je suis entré) dans sa chambre, il (mon père) lisait une lettre. Ger.: Als ich in sein Zimmer trat, las er (mein Vater) einen Brief. Dan.: Da jeg trådte ind $i$ hans vaerelse, laeste han (min far) el breo. Sw.: När ( $D a)$ jag kom in $i$ hans rum, läste han (min fader) et breo.

For older English the question is answered in the affirmative by Einenkel, o. c., $\$ 59 \eta$ : $\gg$ Wird irgend ein Satzteil aus dem Gefüge des

14 Behaghel, o. c. IV, \& 1472; Heyse, o. c., p. 547; for other languages (Gothic, Norse, Old Greek, Russian, etc.) comp. also Hirt, IGr. 5, 346, and o. c. III 220 f; Behaghel, Btr. 53, 405; Delbrück, Synt. Forsch. 4, 14. Both Behaghel and Hirt suppose an Indo-European origin of this word-order, but they also admit other arrangements in our problem.

${ }_{15}$ Jespersen, MEG VII 2.51. The inversion, however, is possible with an intransitive verb (be, come etc.) and a substantival subject, comp.: for, ere I Could dram to part them, mas stout Tybalt slain, Sh., $R$. Jul. III 1; Even mhile they mere talking came a male for adoice, Reade, The Cloister and the Hearth, ch. 52; As they debated the story, came a loud knock at the door, Thack., Van. Fair, ch. 25; While the government of the Tudors mas in its highest vigour, took place (= occurred) an event mhich..., Macauley, Hist. I, ch. 1 (quoted from Poutsma), etc. But usually the weak there ("grammatical subject") is used in the front position of the principal clause, e. g.: As I was sitting at breakfast this morning, there comes a knock at the door, Dick., Chuz., ch. 39 , etc. (see below!).

Poutsma, o. c., P. I, VIII 8 a, also only gives examples with intransitive verbs bearing on our problem: here are, however, two examples of inversion with transitive verbs: But just, mhen all mas fair, and I mas to see him safe aboard ship for Rome, if not to Rome itself, met us that son of a - the Lord Anthony of Burgundy, and his men, making for Flanders, Reade, The Cloister and the Hearth, ch. 48 (here, the inversion is perhaps due to the long apposition, following the subject, "Gesetz der wachsenden Glieder"!); "Hoo," Ringo said. "Me ask her? I bet if she stayed here mouldn't no Yankee nor nothing else bother that trunk, nor Marse John neither, if he knomed hit." W. Faulkner, The Unvanquished, ch. 2.

In Modern French the inversion with intransitive verbs in our construction is possible as well. 
Satzes herausgehoben und emphatisch an die Spitze desselben gestellt, so ruft dies meist Inversion hervor. Das letztere ist im AE. häufig, gegen das Mod. seltener. Dieser Fall, gewöhnlich wie er ist, braucht nicht belegt zu werden, nur der Sonderfall, in welchem, dem AE. unbekannt (?) ein Präp.-Adv, an die Spitze tritt... me. Out goon the stoerdes, Ch., ne. Off goes his bonnet, Sh., Rich. II, mod. On they came, ùä; ${ }^{16}$ sowie ein anderer, in welchem der an die Spitze gestellte Satzteil in ga n z e n (Adverbial-) Sätz e n besteht, verdient Erwähnung: ae. Syððan he com ofer Waetlinga-straete, morhton hi paet maeste yfel, Sax. Chr.; me. pa mile pe heo troeoneden pus, clepede Membricius, La3.; rhanne Cristis chirche prof, weren no sich pope and cardenals, and sipen pes prelatis meren comun yn, regnide anticrist mip synne, Wyclif; ne. not as the morld gives, give I unto you, Sweet, Syntax; mod. (?) If this is not poetry, may the name perish, Acad. 17. Febr. 1900, p. 149.\&

Similarly also Mossé, o. c. II, § 173: «L'ordre inverse verbe-sujet est des plus fréquents en moyen-anglais. Voici les principaux cas où il se présente: ... 7. Après les subordonnées conjonctives placées en tête: and so hi roere in po ssipe, so aros a grat tempeste of roinde, Sermon of Kent; Annd tatt te Laferrd Jesu Crist Wass borenn her to manne..., patt dide he forr to shaeroenn swa Unnsezzenndliz mecnesse, Ormulum 3608.

This is not the view of R. Huchon, o. c. I 257: «... et il est à remarquer que, contrairement à l'usage de l'allemand moderne, une proposition subordonnée précédant la principale n'exerce sur le verbe de cette dernière aucune influence décisive. Aussi écrira-t-on sans inversion: gif pu ponne pis lytle bebod tobrecst, pu scealt deape sroeltan, Hom. Th. I 14, bien que, çà et là dans l'Orose, on ait pu noter quelques constructions inverses telles que: Aefter paem pe Romeburg getimbred maes IIII hunde mintrum \& XXVI, feng Alexander to Macedonia rice, Or., p. 122.》

It thus seems that this question, an interesting one and still at issue for Old French as well, ${ }^{17}$ deserves more attention and research if we are to obtain more exact if not definitive judgments. These we shall try to present in these pages, in so far as our rather limited choice of older texts has allowed us to form them.

Of the examples quoted by Einenkel, his statement is unquestionably confirmed only by the first, Old English instance which in fact

16 For this construction see Jespersen, MEG VII 2.44; Grad, o. c.

${ }^{17}$ Lerch, o. c. III, $\$ 395$ e; Grad, L'inversion du sujet dans la principale précédée d'une subordonnée en ancien fransais, in Razprave $S A Z U$, Ljubljana 1955. 
exhibits the inverted subject in the principal clause, with a transitive verb and its object expressed; but unfortunately it is an isolated instance of inversion, other examples - which we came upon in our texts - with the preceding subordinate opening with siððan exhibit the direct wordorder in the postponed principal clause (see below). ${ }^{18}$ In Einenkel's Middle English examples, however, we find the inverted arrangement with intransitive verbs, and as inversion with such verbs is still possible in Modern English as well, they cannot be considered good evidence for our problem. Nor can the two Modern English examples quoted by Einenkel satisfy us: in the first the inverted arrangement is undoubtedly occasioned by the frontal negative, ${ }^{19}$ and in the second the head-clause represents an optative sentence, expressed by means of the verb may, and, as is known, in such cases the inversion is commonly observed, comp.: May you be happy, etc. ${ }^{20}$

As for the instances quoted by Mossé we think too that they are not well chosen for the purpose of demonstrating the prevalence of the inverted word-order in our field: in hio second example the inversion in the postponed principal clause must be ascribed to the frontal demonstrative object that (comp. also: pat may I ful mel swere, bi God!, Havelok the Dane 252; this thoughte he mel ynoughe That..., Chauc.; still in Mod. English: On Lammas-eve at night shall she be fourteen; That shall she, marry, Sh., RJul. I 3; That shall I do, my liege, Id., Henry the Sixth II, III 2; That mill I learn to-morrom, Scott, The Abbot, ch. $12,{ }^{21}$ while in the first instance it is due to the frontal demonstrative (correlative) adverb so; in older English this, as well as some other

18 In: Syððan furpum meox Of cildhade, symle cirde to him Aehte mine, Cynewulf's Elene 914, the pronoun-subject he is omitted both in the subordinate and the principal clause; in Holthausen's view its place would be after syððan, and symle respectively.

An example of the preceding object-clause with inversion in the following head-clause is furnished by the Lay of Havelok the Dane 29992: And hrou he meren wreken wel, Haue ich sey(d) you euerildel. But comp. also: Wher that he be, $I$ can nat sothly seyn, Chaucer, Cant. Tal., The Milleres Tale.

19 See also Grad, Affectivity and Inversion in Modern English.

2o Jespersen, MEG VII 2.22; Poutsma, o. c., P. I, VIII 21 a.

${ }^{21}$ Comp. Poutsma, o. c., P. I, VIII $8 \mathrm{k}$ : "The word-onder in the following examples, presumably common enough in older English, is now only occasionally met with, except, perhaps, in the language of the illiterate. "He speaks the truth", said a second voice firmly. "Ay, that doth he", said a third, Lytton, Rienzi I, ch. 3." 
demonstratives, such as: $\not a(b o)$, ponne, $p a n(n e), p^{22}$ are very often met with in this position, their function being to link the subordinate and the principal clauses; they appear almost regularly in Old English, less frequently in Middle English when the language began to get rid of them for stylistic reasons; as will be seen, they were far less in use after the subordinates opening with the conjunctions mhen and if than after those introduced by an adverb-conjunction or a compound conjunction. Comp.:

pa he pa se cyning pas mord gehierde, pa het he hie bidan on paen ealande, Bede's Eccl. Hist.; Mid-py he pa Paulinus biscop Godes roord bodade ond larde, ond se cyning elde pa-git to gelyfanne..., pa raes sume daege se Godes rer ingongende to him, ib.; Betroux-pam-pe he clypode to Criste pa-git, pa tugon pa haepenan pone halgan to slaege, Aelfric's Lives of the Saints; pa hie fulle maeron, pa croaep he to his leorning-cnihtum, Gospel, John VI 12; Ac sona-sroa hie to Beam-fleote comon, ond paet geroeorc geroorct raes, sroa hergode he on his rice, Winchester Chr., pa se cyng paet hierde, pa mende he hine rest, ib.; and ponne se cyng raes on Normandige, ponne raes he maegester on pisum lande, Peterborough Chr.; ponne by ylcan daege pe hi hine to haem ade beran millad, ponne todaelađ hi his feoh, Alfred's Geogr. Treatise; Ase hi ferden here rai in pe morementide, penne seyen hi troolf 3ungemen after hem ride, Iacob and Iosep 406; Bot sone rhen he herd ascry pat king Edmard mas nere parby, pan durst he noght cum nere, Laurence Minot; And huanne be mes byep y-come on efter pe oper, panne byep pe burdes and pe trufles vor entremes, Ayenbite of Inwyt (French original: ... lors sont les bordes e les truffes por entremes); And mhan he dromgh to pe dore, panne dymmed his eighen, Piers Plowman 356; Whaenne sma aei ferde funde to pan paerde, peonne fleo pa fuzeles feor $i$ pan lufte, Lazamon's Brut 21748; Whan Zephirus eek with his smete breeth Inspired hath... The tendre croppes... Than longen folk to goon on pilgrimages, Chauc., Cant. Tal., Prol. 5; And shortly, rhan the sonne ras to reste, So hadde I spoken with hem ..., ib. 30; Whanne

22 See Mossé, o. c. I, \$ 191, II, \$ 162 . - Quite similarly the adverbs so, da, and $s i$ (lors), opening the postponed principal clause in older German and older French (and other Romance languages), occasion the inversion of the subject, see Behaghel, o. c. IV, \$ 1472, H. Paul, Mittelhochdeutsche Gr., \$ 355, Lerch, o. c. III, \$ 395 e, Meyer-Lübke, Gram. der rom. Sprachen III, \$ 651.

Mossé's instance is a translation from French: Et si cum furent en la mier, si leva un grant torment. 
dame Prudence... hadde herd al that hir housonde lyked for to seye, thanne axed she of him..., ib., The Tale of Melibeus 15, etc., etc. ${ }^{23}$

With intransitive verbs, we often find the demonstrative local adverb there in the front position of the principal clause, sometimes still having its full local value, but usually already representing the weak there, "a mere anticipative element occupying the place of the subject which comes only later" (OED) (a sort of "grammatical subject"). Thus in: And ealle pa hroile pe paet lic bið inne, paer sceal beon gedrync and plega..., Alfred's Geogr. Treatise; For if re luf God in al oure hert, par es na thyng in us thurgh pe whilk me serve to syn, Rolle of Hampole; And as I mente, ther cam by mee A mhelp..., Chauc., The Book of Duchesse 388; And after pat he hadde endid alle his goodis, per fell a gret hungre in lond, Wyclif, etc. But the weak there may also be omitted, as seen from Einenkel's and other modern examples (see above!), and perhaps this is also the case of Huchon's example with inverted subject (see above!) and intransitive use of the principal verb (fon to rice). ${ }^{24}$

In the same position and after a preceding concessive subordinate, we frequently meet in Middle English the adversative adverb yet which again occasions the inversion, e. g.: Thouz me culled pe catte, zut sholde per come another To cracchy us, Piers Plowman 185 (with inverted weak there); thogh Argus... sete to rekene in hys countour, And rekened with his figures ten... Yet shoulde he fayle to rekene even The rondres..., Chauc., The Book of Duchess 455; For though a midre hadde noght a sho..., Yet molde he have a ferthing, Id., Cant. Tales, Prol. 253; But

${ }^{23}$ The introductory then with the following inversion is still occasionally met with in modern texts: When I have chased all thy foes from hend, Then mill I think upon a recompense, Shak., Henry the. Sixth I, I 2; When they are gone, then must I count my gains, Id., King Richard the Third I 1; If the king offer not a sacrifice of a fair girl.... then shall he fall and his house, Haggard, King Sol. Mines, ch. 11; When the dance is over, then mill I speak to some of the great chiefs, ib., ch. 10.

24 Examples in Old and Early Middle French, similar to Huchon's inverted instance, owe the inverted word-order in the postponed head-clause to the fact that the first part of the compound conjunctions (for inst. apres ce in apres ce que, ainz in ainz que, pour ce in pour ce que, see Grad, o.c.) was in that period still felt as an adverbial adjunct belonging to the head-clause in which it occasioned - owing to its front-position - the inversion of the subject. Similarly, and with the same result, aefter paet (paem) in aefter paem pe could have been felt as part of the postponed head-clause, but other similar (unfortunately extremely rare) examples do not support such a supposition, e. g.: Aefter pan pe ic arise of deađe gesunf, ic eor eft gemete, Aelfric (direct arrangement in the headclause! see below!). 
al be that he was a philosophre, Yet hadde he but litel gold in cofre, ib. 297; And al-be-it so that it seme that thou art in siker place, yet shaltor alreey do thy diligence, ib., The Tale of Melibeus 29; ib.51, etc. Still in Mod. English: But, though thou art adjudged to the death, Yet will I favour thee, Shak., The Comedy of Errors I 1; Although me fancy not the cardinal, Yet must we join with him., Id., Henry the Sixth II, I 3.

The inversion of the subject in the principal clause of the above examples is due to the introductory (correlative) adverb, serving as a connecting link between the subordinate and the postponed principal clause and almost regularly occasioning the inversion (as pointed out by Huchon, l. c., the inversion is especially the rule after short, monosyllabic adverbs; for some exceptions see below!). But as early as that period the language could do without such correlative adverbs in the front position of the principal clause, and - a most important fact concerning our problem! - in this case the principal regularly exhibits the direct, noninverted arrangement, the whole hypotactical group thus already assuming its modern form. Examples with a pronominal subject are especially numerous, comp.:

$\mathrm{OE}$ : And peah man asette troegen faetels full ealað oðঠe raeteres, hy (二 hie) gedoð paet aegber bið oferfroren, sam hit sy sumor, sam minter, Alfred's Geogr. Treat.; Siððan ic hie đa geliornod haefde, sroaesmae ic hie forstod, ond swae ic hie andgit fullicost areccean meahte, ic hie on Englisc amende, Alfred, Letter to Werferth; Aefter pan pe ic arise of deaðe gesunf, ic eor eft gemete, Aelfric (quoted from Einenkel, o. c., p. 27); Ac siððan ठеs 才in sunu com, ðe his spede mid miltestrum amierde, ðu of sloge him faett cealf, Gospel, Luke XV 30; And ða hie ne meahton hine inn bringan for đaere menige, hie openedon đone hrof đaer se Haelend maes, ib., Mark II 5; Soðlice đa se Haelend geseah hiera geleafen, he croaeð to đaem laman, ib.; đa se Haelend đaet on his gaste oncneor, đaet hie sma betreoh him ðohton, he croaeð to him, ib.; And ða he đaem huse genealaehte, he gehierde đone smeg, ib.; むa se Haelend his eagan upp ahof and geseah đaet micel folc com to him, he croaed to Philippe, ib., John VI 4; and pa he paet geseah, he hine forbeah, ib., Luke X 31; ib., Luke X 34; Matthem XII 2; paenne se yrðling unscenঠ pa oxan, ic laede hi to laese, Dialogues of Callings, No. 4; ib., No. 15; Ond ymb XXXI mintra paes-pe he rice haefde, he molde adraefan anne aepeling, Winchester Chr.

ME: And po he herde speken of mete, He molde blepeliche ben pare, The Vox and the Wolf; Als she shulde hise clopes handel On for to don, 
and blame pe fir, She sam perinne a liht ful shir, Havelok the Dane 586; And as I lay and leonede and lokede on pe matres, I slumberde in a slepyng, Piers Plowman 9; ib. 14; As John pe apostel hit syz myth syzt, I syze pat cyty of gret renoun, The Pearl 985; As (John) pise stonez in rorit con nemme, I knem pe name after his tale, ib. 997; And as they sat, they herde a belle clynke, Chauc., Cant. Tales, The Pardoner's Tale 664; Axe not rhy, for though thou aske me, I rol not tellen goddes privetee, ib., The Milleres Tale; But er that he had maad al this array, He sente his knave ..., ib.; but ther - as thou hast told me heer - beforn, that ..., $I$ am al redy to chaunge... ib., The Tale of Melibeus; and mhyl I live a mayde, I mol thee serve, ib., The Knightes Tale; For thogh the feend to hir y-coupled mere, She rolde him overmacche, ib., The Marchantes Tale; For that he schold almay upon hir thinke, Sche yaf him such a maner love-drinke, Id. (quoted from Einenkel, o. c., p. 110); And sypen I have in pis hous hym pat al lykez, I schal ware my whyle wel, Sir Gawain and the Green Knight 1234; Bot po sche ran so up and doun, Sche made many a monder soun, Gower, Conf. Am. 4097, paz pou ssoldest to cleve, ich nelle nazt lete asskapie pis mes (despite the French original with inverted subject: Se tu devoies crever, ne lairai-je pas ce mes eschaper), The Ayenbite of Inwyt. ${ }^{25}$

The direct word-order is especially very frequent after the temporal subordinate opening with the conjunction when whose use was spreading more and more in Middle English, presenting also numerous examples of the subordinate preceding the principal clause, as in: Hran he felede hise foos, He made hem lurken, Havelok the Dane 67; ib. 1848; And quhen the kyngis hounde has seyn Thai men assale his master sroa, He lap till ane..., The Bruce 451; huan he comp ayen he hep al pis vorlore, Ayenbite of Inwyt 69; And mhan pat ony gode knyght pat ras hardy and noble cam to see this rialtee, he rolde lede him into his paradys, Manderville's Travels; Hmen pu bihaldest te mon $p u$ art in Eve point, Ancrene Riwle; Vor hmanne hin longeth, ich him singe, The Owl and the Nightingale 890 ; ib. 894; Whan he ros up of his orysoun, He zede yn hys celle up and domn, Handlyng Synne 4033; Whan sche pis vertu hadde sein, Sche let pe leste drope... doun falle, Gower, Conf. Am.4146;

${ }^{25}$ Cases (with a personal pronoun as subject) of non-inverted word-order in our problem are also met with in Middle High German, see H. Paul, l. c., and V. Michels, Mittelhochdeutsches Elementarbuch, 3. Aufl., \& 313, Anm. 2. The non-inverted arrangement disappeared towards the end of the Middle High German period. 
Whan Melibeus retourned mas in-to his hous, and saugh al this meschief, he, lyk a mad man... gan to mepe, Chauc., The Tale of Melibeus 2165, etc., etc.

The non-inverted arrangement is also the rule after a conditional subordinate introduced by gif (if); numerous examples are afforded by Old and Middle English, comp.: Gif ge me ut adrifað fram eorrum geferscipe, ge etað myrta eorre grene, Aelfric's Colloquy, Se Coc; gif ic roiste hroaet he maere, ic molde licgan aet his forum, Id. (quoted from Einenkel, o. c., $\$ 13$ ג); Gif ge so lice miston hroaet is, Ic mille mildheortnesee, Gen.; and gyf par man an ban finde unforbaerned, hi hit sceolan miclum gebetan, Alfred's Geogr. Treat.; gif he moste pa-gyt troa gear libban, he haefde Yrlande gerounnon, Peterborough Chr.; zef hit nere for mi luue, He nere nozt fram his londe icome, Floriz and Blauncheflur 737 ; ib. 677; if ich pe holde on mine uote... And pu mere ot of pine rise, $p u$ sholdest singe an oper mise, The Owl and the Nightingale 51; ib. 209; And if we grucche of his gamen he rill greoe us alle, Piers Plow. 155; Yif $y$ late him lives go, He mihte me mirchen michel roo, Havelok the Dane 509; If ihc come to live Ihc schal pe take to myve, King Horn 559; if he rol nat tarie, ... me rol this tresor carie..., Chauc., Cant. Tal., The Pardoner's Tale 799, etc. etc. ${ }^{26}$

[Inversion, however, seems to have been observed after the negative, thrown by emphasis to the front position of the principal clause, e.g.: Gif pu maere her, naere min broðor dead, Gospel, John (quoted from Einenkel, p. 27); Gif he nere yfel myrcende, ne sealdon we hyne naefre pe, Ev. Nic. (Id., p. 28); if ich me holde in mine hegge, Ne recche ich neuer mhat pu segge, The Owl and the Nightingale 59; ib. 56; Though men me rolde al in-to peces tere, Ne shal I never... Birorenge a roord, Ch., C.T., The Shipmannes Tale; the two Old English examples, quoted by Behaghel, o. c. IV, \$ 1472: gif hit đanne cucu feoh maere, ne pearf he paet geldan, Lieberm. 34, 28; se ðe slea his agene peorne esne, ne bið he ealles stra scyldig, ib. 32,17 , also owe the inversion in the head-clause to the stressed frontal negative (Behaghel ascribes it to the preceding subordinate); comp.also: peah sumum men gesceote laesse dael, ne bið sma-ðeah na mare miht on đam maran daele ponne on đam laessan, Aelfric, Eucharist.

${ }^{20}$ In Old and Middle French as well, preceding subordinates opening with the conjunctions quand and si do not, as a rule, occasion inversion in the postponed head-clause, see Grad, o. c. 
For the front-position of the negative, followed by the verb, see also Behaghel, o. c. IV 12, and Hirt, o. c. III 223.

Of course, examples - though not very numerous - with an introductory demonstrative and the inverted arrangement are to be found as well; thus in: Gif ge for-ðy me fram adrifað, Јaet ge đus don, Jonne beo ge ealle traelas, Aelfric's Colloquy, Se Coc (Latin text: ..., tunc eritis omnes coci); gif ure godo aenige mihte haefdon, ponne roldan hie me ma fultumian, Bede's Eccl. Hist., and gyf me aenige bote gebidan sculan, ponne mote me paes to Gode earnian, Wulfstan, Homily; Gif me ða gastlican mihte ðaer-on tocnamað, ðonne undergyte me...., Aelfric, Eucharist; with the direct word-order in spite of the frontal adverb: Gif ic aenegum pegne peoden-madmas geara forgeafe, ... ponne he me na on leofran tid leanum ne meahte minre gife gyldan, Genesis.]

The direct word-order after the conditional subordinate might be brought about by analogy with examples in which the conditional subordinate (protasis) appears without the conjunction if and with the subject inverted (originally this construction represented an interrogative sentence), and with the non-inverted arrangement in the principal clause (apodosis, representing the answer to the preceding question), as in: Ahte ic minra honda gerweorc... ponne ic mid pys merode..., Caed., Gen. (from Einenkel, p. 45); ablinde be heorte, heo is ed ouercumen, Anc. R. (ib.); Ich mihte habbe bet $i$-don, hefde ich pen $i$-selðe, Poema Morale; for nadde they but a shete... And a bak..., They rolde hem selle ..., Chauc., C.T., The Chanouns Yemannes Tale, etc. ${ }^{27}$

We think, however, that such examples could not but strengthen the tendency to produce the direct word-order in our field - the same construction is to be found in German as well, and nevertheless the direct arrangement has not been introduced in the postponed principal clause ("Nachsatz", cp. Behaghel, o. c. IV, \$ 1472) - but not cause it directly, because it also appears very early after subordinates of other kinds, as seen from our examples above. A marked tendency to form the direct word-order is also evidenced by instances in which we meet the non-inverted subject even after a frontal object, and adverbial adjunct respectively, comp.: pa hi ford eodon, feores hi ne rohton, The Battle of Maldon; Hran he havede 't greyped so, Havelok pe yunge he dede perinne, Havelok the Dane 714; Whan Melibeus hadde herd that..., anoon he consented to hir conseiling, Chauc., C.T., The Tale of Melibeus

${ }^{27}$ This is the view of Behaghel, Q. c. IV, $\$ 1472$. 
2240; Whan th' orisoun was doon of Palamon, His sacrifice he dide, ib., The Knightes Tale, etc.

Parallel (and perhaps by analogy) with the numerous cases of the direct arrangement in the principal clause with a pronominal subject, we also see, as early as the old period and especially in Middle English, the non-inverted substantival subject appear; thus in:

pa hit (sc. saed) up eode, seo sunne hit forstoaelde, Gospel, Mark IV 5; Til pe lizt of day sprang, Ailmar him puzte lang, King Horn 493; Annd sone anan se piss rass sezzd purrh an off Godess enngless, A mikell here off enngleped Was cumenn ut off heffne, Ormulum 3368; Gif troa men oper III coman ridend to an tun, al pe tunscipe flugaen for heom, Peterborough Chr.; panne sho havede brouht pe mete, Haveloc anon bigan to ete, Havelok the Dane 649; ib. 474, 657, 1824; pa hit mes daei a marzen..., Arður pa up aras and strehte his aermes, La3. Brut 14003; Whanne ich zong mas... meny zer hennes, My fader and my frendes founden me to scole, Piers Plow. VI 55; zif ze in pis londe mid pefpe bep ifonge, zoure dom is idemed, Iacob and Iosep 413; When pe nyhtegale singes, pe modes maxen grene, Suete Lemmon; Whan they han goon nat fully half a mile,... An oold man and a poore mith hem mette, Chauc., C. T., The Pardoner's Tale 211; And also sone as that he mas gon, That oon (of hem) spak thus unto that oother, ib. 806; And whan this abbot had this monder seyn, His salte teres trikled doun as reyn, ib., The Prioresses Tale; Whan that they comen... out of toune, This Somnour... gan to roune, ib., The Freres Tale; Whan that our pot is broke..., Every man chit, and halt him yoel apayd, ib., The Chanouns Yemannes Tale; Whan we came to the forest syde, Every man dide ryght anoon As to huntynge fil to doon, Id., The Book of Duchesse 372; paz ho (= she) rere burde bryztest, pe burne in mynde hade pe lasse luf in his lode, Sir Gawain and the Green Knight 1283; And zit mhanne he mas fer, his fadir same him, Wyclif, etc. (most examples are again furnished by the subordinates opening with the conjunctions mhen and if).

Thus the preceding pages may have shown the following results concerning the problem of word-order in the principal clause preceded by an adverbial subordinate in Old and Middle English: ${ }^{28}$

${ }^{28}$ It should be pointed out that such hypotactical constructions are not very frequent, especially in the oldest stage of the language, its characteristic feature being the loose association of clauses (parataxis; for this problem s. also Klaeber, Anglia Beibl. 52, $216 \mathrm{ff}$, and Anglia 25, $275 \mathrm{ff} ; 27,246$ ); only in Middle English 
a) The inverted word-order (VS) is the rule after an introductory demonstrative (correlative) adverb almost regularly used in Old, less frequently in Middle English in the front-position of the postponed (declarative) head-clause;

b) whenever the demonstrative (correlative) adverb does not appear in this position - and such examples are far from being rare, they are almost the rule after subordinates opening with the conjunction rhen and especially if - it is the direct arrangement that had already asserted itself not only with a pronominal but also a substantival subject; some instances (especially with a pronominal subject) are to be found as early as Old English, and they become quite frequent in Middle English, proving that in this case, too, the tendency in English to resort to the direct (logical) word-order began to take root at this early date without having undergone any foreign influence, thus presenting an important divergence from other Germanic languages in this respect; ${ }^{29}$

c) examples of the inverted arrangement in the non-introduced postponed head-clause can be found with intransitive verbs, which, however, already in that period, are frequently preceded by the weak "there"; in some cases the inverted word-order is occasioned by a negative, thrown by emphasis to the front-position of the postponed principal clause.

\section{Povzetek}

Prispevek $k$ problemu besednega reda $v$ stari in srednji angleščini

V začetku članka omenja avtor, da je raba invertiranega besednega reda (VS) $\mathrm{v}$ asertivnih stavkih $\mathbf{v}$ moderni angleščini na eni strani mnogo redkejša kot $\mathrm{v}$ drugih germanskih jezikih $-\mathrm{v}$ tem pogledu gre angleščina vzporedno $\mathrm{s}$ francoščino -, na drugi strani pa tudi redkejša kot $\mathrm{v}$ starem jeziku, $\mathrm{v}$ katerem je splošno nastopila inverzija subjekta $\mathrm{v}$ tako imenovanih uvedenih stavkih, t. j. takih, ki so se začenjali s kakim drugim stavěnim ǒlenom kot osebkom: tako n. pr. je lahko zaradi posebnega poudarka stopil na čelo stavka bodisi

when parataxis gives way to more precise indications of logical relationship and subordination (hypotaxis) do cases of our construction appear in a greater number.

${ }^{20}$ For similar hypotactical constructions in Middle High German, functional differences (concerning the subordinate) for cases mentioned under a), and those under b) respectively, are supposed by Karg, Hypotaxe bei Hartmann von Aue, Germanica (Festschrift für Sievers, 1925), p. 455. 
objekt bodisi prislovno določilo in pritegnil $\mathbf{k}$ sebi (na drugo mesto $\mathbf{v}$ stavku) glagol, medtem ko je osebek moral zavzeti mesto za glagolom. Vendar avtor poudari dejstvo, da je tudi $\mathbf{v}$ uvedenih stavkih raba direktnega (logičnega) besednega reda $(S V)$ že $\mathrm{v}$ stari dobi tudi možna in razmeroma kar pogostna, zlasti $\mathbf{v}$ primerih, ki imamo $\mathbf{v}$ njih osebek izražen $z$ osebnim zaimkom. Taki primeri po avtorjevem mnenju potrjujejo Jespersenovo domnevo, da se je direktni red začel $\mathbf{v}$ angleščini uveljavljati že pred razpadom stare fleksije, oziroma da ni šele le-ta povzročil njegovega nastanka, kot se to splošno domneva. Zanimivo je, da so zadevni primeri $\mathbf{v}$ starejši angleščini pogostnejši kot $\mathbf{v}$ istodobni francoščini (ki je tudi poznala in zelo dosledno spoštovala pravilo o inverziji $\mathrm{v}$ takih primerih), kar - hkrati $\mathrm{z}$ dejstvom, da $\mathrm{v}$ prevodih tiste dobe iz francoščine, kjer $\mathbf{v}$ originalu srečamo še invertirani subjekt, že najdemo direktni besedni red $\mathrm{v}$ angleškem tekstu - nikakor ne govori za to, da bi bila angleščina prešla $\mathrm{k}$ logičnemu redu pod francoskim vplivom, kakor nekateri mislijo.

Predmet sprednje razpravice je še sporno vprašanje, ali je angleščina $v$ stari dobi tudi poznala inverzijo subjekta $\mathbf{v}$ (asertivnem in neuvedenem) glavnem stavku, pred katerim je stal adverbialni podredni stavek, kar je strogo pravilo $\mathbf{v}$ moderni nemščini in $\mathbf{v}$ skandinavskih jezikih, ne pa zopet $\mathrm{v}$ francoščini. Na podlagi primerov, ki jih je našel $\mathbf{v}$ dosegljivih $\mathrm{mu}$ starih tekstih, je avtor glede tega problema prišel do naslednjih zaključkov:

a) invertirani besedni red $\mathrm{v}$ zapostavljenem glavnem stavku je pravilo za uvodnim demonstrativnim (korelativnim) adverbom, ki se je v stari angleščini skono dosledno, manj pa $\mathrm{v}$ srednji angleščini rabil na čelu glavnega stavka ter povzročil inverzijo. Taki demonstrativni adverbi so bili: pa, so, panne, pere (prim. nem. so, dann ter starofranc. si, lors $\mathrm{v}$ isti poziciji ter $\mathrm{s}$ prav tako sledečo inverzijo);

b) kadar koli pa takega korelativnega adverba ni bilo - in taki primeri niso izjemni niti $\mathrm{v}$ najstarejši dobi in postajajo vse pogostnejši $\mathrm{v}$ srednji angleščini ter zlasti skoro ne poznajo izjem za odvisniki, uvedenimi z veznikom rhen ter zlasti if - pa že srečamo direktni besedni red, in sicer zopet predvsem $\mathbf{v}$ primerih s pronominalnim subjektom ter, verjetno pod vplivom le-teh, tudi že v primerih s substantivnim subjektom; tudi tu je torej logični red brez tujih vplivov pognal močne korenine že $\mathrm{v}$ tej dobi ter ustvaril pomembno razliko k drugim germanskim jezikom;

c) primeri obratnega besednega reda $\mathrm{v}$ našem problemu se najdejo pri intranzitivnih glagolih (kar je možno še danes), a so že v oni dobi često uvedeni s šibkim prislovom there (sgramatikalniء subjekt); $\mathbf{v}$ nekaterih primerih pa moremo pripisovati inverzijo nikalnici, ki jo je emfaza postavila na začetek glavnega stavka in ji je (kot še danes $\mathrm{v}$ nekaterih primerih) neposredno sledil glagol, a le-temu šele subjekt.

Podrobnosti ter navedbo strokovne literature glej $\mathbf{v}$ angleškem besediłu razprave oziroma $\mathrm{v}$ opombah. 